\title{
Analysis of the Current Situation of China- Myanmar Bilateral Economic Cooperation
}

\author{
Tang Liujie* \\ International Business School \\ Yunnan University of Finance and Economics \\ Kunming, China \\ yyw1101@163.com
}

\author{
Zou Ziye \\ International Business School \\ Yunnan University of Finance and Economics \\ Kunming, China \\ 490471958@qq.com
}

\begin{abstract}
Building a good partnership with its neighbors is the basic principle of Chinese foreign policy raised by President Xi Jinping. Myanmar plays a significant role in linking Southeast and South Asia. So Myanmar is an important country for China to implement the "One Belt, One Road" opening-up policy. Myanmar and China become major trade partners. The article analyzes the importance of a healthy surrounding economic environment which can stimulate sustainable development of China. Through the comparison between EU and ASEAN integration, the article analyzes the bilateral trade and the potential capacity between China and Myanmar.
\end{abstract}

Keywords-China; Myanmar; Economics; Gravity Model

\section{INTRODUCTION}

In 2013, the national strategic concept "One Belt, One Road" which consists of the "Silk Road Economic Belt" and twenty-first Century "Maritime Silk Road" was raised by Chinese President Xi Jinping. The strategy not only adapts to the world economic situation, promotes the integration of China and the world economy, accelerates the comprehensive construction of China's open economic system, but also shares the benefits with countries along the planning line of this strategy. In "One Belt, One Road" strategy, Myanmar is a significant part. So it is important for China to enhance the economic cooperation with Myanmar.

The significance of bilateral economic relation between China and Myanmar can be summarized into the following parts: Firstly, it is good for China to transform regional economic structure. Since the opening-up reform, China has already formed a "dual economic structure", which means development differences among regions. In a long time, the eastern region plays the role of "department of industry", whiles the central and western plays the role of "agricultural sector" and "natural resource supplier", which was influenced by national policy tilts, FDI in the eastern region and the ruralurban migration. But now, economic development speed has begun to slow down due to the low level industrial production and the diminishing demographic dividend. In order to promote economic sustainability, China has put forward "One Belt, One Road" strategy to develop the western area which has a close relationship with Myanmar. Secondly, it is good for China to diversify natural gas sources, as well as other energy sources and transfer industrial production outward. Due to the high growth rate, China has changed the development patterns from labor intensive industry, attracting inward FDI and foreign advanced technology to re-balance the economy by improving technology innovation. According to statistics, by the end of 2014, China has become a net capital exporter. By implementing "One Belt, One Road" strategy, China could seize the opportunity of accelerating the factor flows, removing the excess capacity and increasing foreign exchange amount. Myanmar has rich resources and broad market which will make Myanmar become an important partner in this strategy. Thirdly, by strengthening the cooperation with Myanmar, it is good for the two countries to promote friendship and maintain peaceful environment. It is also good for China to build the four economic corridors including the economic corridor of Kunming to Rangoon, Kunming to Hanoi, Kunming to Calcutta and Kunming to Bangkok. The constructions can help China maintain energy security. Lastly, it is China's responsibility to fulfill the aim of WTO and policies to integrate into the world further by strengthening the bilateral economy with Myanmar.

\section{COMPARATIVE ANALYSIS OF REGIONAL ECONOMIC INTEGRATION}

\section{A. The impact of EU integration on economy and trade}

Regional economic integration is a process of national economic integration which means to establish an institution beyond national government authority and formulate unified foreign economic and fiscal policy. It can provide an economic community with high degree of harmonization which can remove regional economic and trade barriers and promote regional mutual reciprocity and mutual benefit. The most successful regional economic integration until now is the European Union (EU). In 1951, the European Coal and Steel Community was established, and in 1958, the EU was formally established. During that period, the EU took measures to reduce tariffs and enhance the free flow of labor and capital in each country. These influences which are called "agglomeration effect" have attracted more countries to join in the EU which stimulates economy and improves the political influence. The influence is not only in the economic field but

\footnotetext{
* Corresponding author
} 
also in non-economic area, such as cultural communication and political stability.

The target of countries to participate in the regional economic integration is to maximize their own benefits. In order to achieve this goal, countries will transfer some sovereignty such as the right to make national policy. The unified regional policies which are made by the EU could narrow the regional gap among member states and promote the common and harmonious development. In the process of promoting the economic development of its members, the EU has paid attention to the following aspects when maximizing the interests:

- When adopting the regional policy framework, EU has made the framework more clear and systematic. Most EU countries have had the relatively complete legal norms and institutional basis which made it possible for EU to take feasible regional policy to promote the coordinated development of regional economy.

- The EU has sufficient financial support to maintain the regional policy. In order to allocate capital in the region, EU has established several funds like European Financial Stability Facility (EFSF). By using these funds, EU has supported some backward areas' development and infrastructure construction projects.

- The EU has a clear policy goal which gave considerations to both efficiency and fairness. The EU ensures its efficiency and fairness by setting a series of policies to promote social security.

\section{B. The deficiency of China-Myanmar bilateral cooperation}

1) Status quo of Association of Southeast Asian Nations (ASEAN) Integration: In a long time, the China-Myanmar bilateral cooperation has lagged behind. So if we want to analyze the status quo of the China-Myanmar bilateral economic development, we should focus on the ChinaASEAN Free Trade Area (CAFTA) which could present the recent development between China and Myanmar. CAFTA is comprised of 11 countries, including China and ten ASEAN countries which are close to each other and have long history of economic and cultural communication. The difference and complementarity of resource endowment have brought China and ASEAN to cooperate. In 1991, the trade volume between China and ASEAN grew rapidly. In 1991, the total bilateral trade between China and ASEAN was only $\$ 6.3$ billion, while in 1996 increased to $\$ 20$ billion, and in 2014 , to 480.4 billion. In 2010, CAFTA started to work which has been the largest FTA with the largest population among the developing countries. According to the theory of international trade, regional economic integration will increase trade creation benefits, reduce the cost of trade among member states, help to gain mutual complementary advantages and achieve largescale benefits.

At the same time, it is also conducive to the members to upgrade their economic structure. After setting up the FTA, the China-ASEAN economy and bilateral trade have been further improved. The key of "One Belt, One Road" initiative lies in the development of infrastructure construction and transportation along the way, and to build an internet work among all the cooperative states. With cooperation deepening, the ASEAN members have developed rapidly. According to the world investment report issued by United Nations Conference on Trade and Development in 2015, China's agricultural products exporting to ASEAN countries were more than 7 billion during 1-7 months in 2015 .

But compared with the EU's integration, ASEAN has just reached to the second stage of regional economic integration i.e. FTA stage. The reason for ASEAN's integration speed falling behind is that ASEAN had no same background with the EU, so ASEAN couldn't gain all the benefits generated by integration. Moreover, ASEAN and the EU have different integration process. The EU's development started from mutual economic benefits. And then, the huge benefits generated by integration led to further integration of politics. Compared with the EU, the main purpose for countries to set up ASEAN is political i.e. to protect their own security interests and maintain strategic relationship with the West. And its activity was limited to economic and cultural exchanges which don't have the driving force to push the integration process further. On the aspect of entering barriers, ASEAN don't have high threshold requirements. All the Southeast Asian countries which hold the common purposes and principles could join in. However, the applicant states to join the EU should have reached the entry requirements, such as the fiscal deficit to GDP proportion, consumer price index level. The EU strengthened subsidies for countries with lower economic level or imperfect system before entering in order to promote fairness and efficiency of all members.

In a unified legal system, ASEAN is far behind the EU. The EU requires that all members must abide by all laws with legal force, such as "Stability and Growth Pact" (1996), "New Currency Exchange Rate Mechanism" (1996) and "the Amsterdam treaty" (1997). It was until 2008 that ASEAN had issued the first universal law, "ASEAN Charter".

\section{2) Trade Structure Similarity Coefficient}

Members of ASEAN except Thailand were once the Western colonies. In the long colonial period, members of ASEAN were mainly cheap raw material origin of the western countries. That was why ASEAN agriculture had developed further than industry and made economic development underdeveloped. And in the process of industrialization, the member countries also encountered problems such as overlapping investment, shortsighted industrial policy, unbalanced structure.

The same economic structure that existed in ASEAN member states for a long term could lead to the competition which is not good for the internal development. In order to measure the industrial similarity, we use structure similarity coefficient to measure Malaysia and Thailand. The equation for calculating the structural similarity coefficient is:

$$
S_{i j}=\frac{\sum_{k=1}^{n}\left(X_{k i} X_{k j}\right)}{\left(\sum_{k=1}^{n} X_{k i}^{2} \cdot \sum_{k=1}^{n} X_{k j}{ }^{2}\right)^{1 / 2}}
$$


In equation (1), $X_{k i}$ and $X_{k j}$ represent the proportion of the output value of $K$ industry in area $I$ and $J$ separately. $S_{i j}$ stands for the industrial structure similarity coefficient. The value of $S_{i j}$ is between 0 and 1 . If $S_{i j}$ is close to 1 , it means the two areas' structure are similar in a great degree. Based on three industries to GDP proportion, the structural similarity coefficients of different years are shown in Table I .

TABLE I. Industrial Structure Similarity Between Malaysia AND THAILAND

\begin{tabular}{|c|c|}
\hline Year & Structural Similarity Coefficient \\
\hline 2002 & $99.51 \%$ \\
\hline 2003 & $99.52 \%$ \\
\hline 2004 & $98.96 \%$ \\
\hline 2006 & $98.93 \%$ \\
\hline 2007 & $99.19 \%$ \\
\hline 2009 & $99.94 \%$ \\
\hline 2010 & $99.43 \%$ \\
\hline 2011 & $99.97 \%$ \\
\hline
\end{tabular}

Table I shows that the ASEAN industrial structure similarity coefficient is very high. In the dynamic point of view, the internal industrial structure similarity shows divergence in 2004 to 2007. But after 2009, the similarity rebounded. Comparative advantage in the economic integration would be reduced if there was industrial isomorphism in the member countries. Industrial isomorphism would cause the repeat construction and malignant competition which are not good for economic development. At the same time, the problems that have existed in the ASEAN regional development will influence the economic cooperation between China and ASEAN.

\section{3) China-Myanmar Trade Structure}

Compared with the ASEAN members, China and Myanmar industrial structure similarity coefficient is smaller which indicates that China and Myanmar have industrial structure complementarily (Table II ). It is good for industrial structure adjustment and industry transfer.

TABLE II. IndUStRial Structure Similarity BETWEen China AND MYANMAR

\begin{tabular}{|c|c|}
\hline Year & Structural Similarity Coefficient \\
\hline 2009 & $85.11 \%$ \\
\hline 2010 & $85.05 \%$ \\
\hline
\end{tabular}

To analyze the trade data separately, the study uses the import and export trade volume of the two countries. According to the standard international trade classification (SITC, the fourth amendment standards), import and export products were classified into ten categories which was numbered 0-9 respectively. The SITC classification standards divided the products into primary products (0-4 category) and manufacturing products (5-9 category). So the paper summarized the import and export data as follows:
TABLE III. CHINA's EXPORTS TO MYANMAR (MILLIONS OF DOLlARS)

\begin{tabular}{|c|l|l|l|l|}
\hline Category & \multicolumn{1}{|c|}{$\mathbf{2 0 1 1}$} & \multicolumn{1}{c|}{$\mathbf{2 0 1 2}$} & \multicolumn{1}{|c|}{$\mathbf{2 0 1 3}$} & \multicolumn{1}{c|}{$\mathbf{2 0 1 4}$} \\
\hline 0 & 58.49 & 63.46 & 121.26 & 201 \\
\hline 1 & 46 & 50.89 & 57.56 & $56 ., 58$ \\
\hline 2 & 32.50 & 44.37 & 58.99 & 166.71 \\
\hline 3 & 151.49 & 192.43 & 220 & 289.28 \\
\hline 4 & -- & 68.25 & 56.35 & 61.40 \\
\hline 5 & 279.33 & 284.09 & 365 & 456.83 \\
\hline 6 & $1,704.69$ & $1,938.18$ & $2,811.94$ & $3,521.62$ \\
\hline 7 & $2,210.50$ & $2,611.22$ & $3,164.21$ & $3,611.46$ \\
\hline 8 & 338.16 & 489.01 & 539.24 & $1,064.04$ \\
\hline 9 & 286.37 & -- & 391.05 & -- \\
\hline
\end{tabular}

TABLE IV. China Imports From Myanmar (Millions of Dollars)

\begin{tabular}{|c|c|c|c|c|}
\hline Category & $\mathbf{2 0 1 1}$ & $\mathbf{2 0 1 2}$ & $\mathbf{2 0 1 3}$ & $\mathbf{2 0 1 4}$ \\
\hline 0 & 141.89 & 169.72 & 156.75 & 163.04 \\
\hline 1 & 0.003 & 0.35 & 0.34 & 0.08 \\
\hline 2 & 640.37 & 665.05 & $1,206.82$ & $1,349.28$ \\
\hline 3 & 69.49 & 62.81 & 201.80 & $1,370.72$ \\
\hline 4 & -- & 0.034 & 0.37 & 0.26 \\
\hline 5 & 4.86 & 8.35 & 5.60 & 9.50 \\
\hline 6 & 790.09 & 282.22 & $1,089.64$ & $12,145.54$ \\
\hline 7 & 0.27 & 6 & 21.22 & 25.04 \\
\hline 8 & 32.86 & 103.64 & 174.30 & 537.22 \\
\hline 9 & -- & 0.003 & -- & 0.54 \\
\hline
\end{tabular}

Table III - IV show that Myanmar's exports are mainly primary products. On the contrary, Myanmar's imports are mainly manufacturing products from China. China's seventh category of exports is the major part of export products to Myanmar, while Myanmar's exports to China are mainly in second category namely "non-food raw materials" which are the resource-based products. The motive force of bilateral trade lies in the economic differences. However, because of the manufacturing industry development of Myanmar lagging behind, Myanmar's exports are in low level which make most products lack of competitiveness. Compared to the close bilateral political relation, the bilateral economic and trade development has been lagged in long-term. The reason is that Myanmar's domestic economic development is underdeveloped and the low purchasing power is difficult to meet the capital needed for import that makes imports grow more slowly. Another reason is that the domestic manufacturing industry in Myanmar grows slowly. It is difficult to provide high quality products for export. On the contrary, China has great market demand, highly complementary with Myanmar. Maintaining good development momentum will make future bilateral trade promising. In 2014, China-Myanmar bilateral cooperation has made great achievements when Myanmar was shouldering the ASEAN's rotating presidency. At same time, the exports from Myanmar to China have changed greatly. The sixth category have increased by a large margin which means that the bilateral 
economic development structure and the types of goods have been optimized between China and Myanmar.

Even though China-Myanmar bilateral economic import and export trade has increased in recent years, Myanmar to China's huge trade deficits will cause bilateral trade friction which are not good to the China-Myanmar bilateral economic development. In light of current trends, the long-term trade deficit situation has been improved which shows a stable development and trade cooperation.

\section{ANALYSIS OF THE BILATERAL ECONOMIC RELATIONSHIP BASED ON TRADE GRAVITY MODEL}

\section{A. Trade Gravity Model}

The origin thought of the gravity model came from the law of universal gravitation. The gravity of two objects is proportionate to the quality of them, and is inversely proportional to the distance. The trade gravity model uses this theory which means the bilateral trade scale is proportional to the two sides' economic output, and is inversely proportional to the distance. The basic form of the gravity model is:

$$
T_{i j}=A\left(Y_{i} * Y_{j}\right) / D_{i j}
$$

In the equation (2), $i$ stands for China, $j$ for Myanmar. $T_{i j}$ is the data of China to Myanmar's import and export volume. $Y$ denotes the size of the national economy which is measured by GDP. $D_{i j}$ stands for the economic distance between the two countries which can be measured by the distance between the political center of China and Myanmar. Then, this study transforms the equation (2) into the linear form.

$$
\operatorname{Ln} T_{i j}=\beta_{0}+\beta_{1} \operatorname{Ln} Y_{i} Y_{j}-\beta_{2} \operatorname{Ln} D_{i j}+\xi
$$

\section{B. China-Myanmar Statistical Analysis}

In recent years, the bilateral trade has been greatly developed. China-Myanmar's total bilateral import and export data are as the following (Table V, VI):

TABLE V. ChINA(C)-MYANMAR (M) BILATERAL TRADE IMPORT AND EXPORT VOLUME (MILLIONS OF DOLLARS)

\begin{tabular}{|l|c|c|c|c|c|c|}
\hline \multicolumn{1}{|c|}{ Year } & $\mathbf{1 9 9 7}$ & $\mathbf{1 9 9 8}$ & $\mathbf{1 9 9 9}$ & $\mathbf{2 0 0 0}$ & $\mathbf{2 0 0 1}$ & $\mathbf{2 0 0 2}$ \\
\hline Export (M to C) & 66.7 & 56.0 & 92.3 & 113.5 & 122.0 & 124.5 \\
\hline $\begin{array}{l}\text { Import (M from } \\
\text { C) }\end{array}$ & 626.7 & 586.2 & 447.2 & 546.0 & 547.3 & 797.3 \\
\hline Total Amount & 693.4 & 642.2 & 539.5 & 659.5 & 669.2 & 921.8 \\
\hline \multicolumn{1}{|c|}{ Year } & $\mathbf{2 0 0 3}$ & $\mathbf{2 0 0 4}$ & $\mathbf{2 0 0 5}$ & $\mathbf{2 0 0 6}$ & $\mathbf{2 0 0 7}$ & $\mathbf{2 0 0 8}$ \\
\hline Export (M to C) & 154.1 & 188.0 & 249.5 & 229.7 & 336.9 & 585.9 \\
\hline $\begin{array}{l}\text { Import (M from } \\
\text { C) }\end{array}$ & 998.7 & $\begin{array}{c}1,032 . \\
4\end{array}$ & $\begin{array}{c}1,028 . \\
4\end{array}$ & $\begin{array}{c}1,328 . \\
0\end{array}$ & $1,861.1$ & $2,177.1$ \\
\hline Total Amount & $1,152$. & $\begin{array}{c}1,220 . \\
4\end{array}$ & $\begin{array}{c}1,277 . \\
9\end{array}$ & $\begin{array}{c}1,557 . \\
6\end{array}$ & $2,198.0$ & $2,763.0$ \\
\hline \multicolumn{1}{|c|}{ Year } & $\mathbf{2 0 0 9}$ & $\mathbf{2 0 1 0}$ & $\mathbf{2 0 1 1}$ & $\mathbf{2 0 1 2}$ & $\mathbf{2 0 1 3}$ & $\mathbf{2 0 1 4}$ \\
\hline Export (M to C) & 586.9 & 873.6 & $\begin{array}{c}1,524 . \\
9\end{array}$ & $\begin{array}{c}1,181 . \\
2\end{array}$ & $2,554.2$ & $\begin{array}{c}14,162 . \\
0\end{array}$ \\
\hline $\begin{array}{l}\text { Import (M from } \\
\text { C) }\end{array}$ & $\begin{array}{c}2,507 . \\
0\end{array}$ & $\begin{array}{c}3,828 . \\
8\end{array}$ & $\begin{array}{c}5,307 . \\
5\end{array}$ & $\begin{array}{c}6,242 . \\
5\end{array}$ & $8,084.0$ & $\begin{array}{c}10,312 . \\
4\end{array}$ \\
\hline Total Amount & $3,093$. & $\begin{array}{c}4,702 . \\
4\end{array}$ & $\begin{array}{c}6,832 . \\
4\end{array}$ & $\begin{array}{c}7,423 . \\
7\end{array}$ & $10,638$. & $\begin{array}{c}24,474 . \\
4\end{array}$ \\
\hline \multicolumn{7}{|c|}{} \\
\hline
\end{tabular}

TABLE VI. GDP OF CHINA AND MYANMAR(BILlions OF DOLLARS)

\begin{tabular}{|c|c|c|c|c|c|c|c|c|c|}
\hline Year & $\mathbf{1 9 9 7}$ & $\mathbf{1 9 9 8}$ & $\mathbf{1 9 9 9}$ & $\mathbf{2 0 0 0}$ & $\mathbf{2 0 0 1}$ & $\mathbf{2 0 0 2}$ & $\mathbf{2 0 0 3}$ & $\mathbf{2 0 0 4}$ & $\mathbf{2 0 0 5}$ \\
\hline China & 2,713 & 2,925 & 3,148 & 3,413 & 3,697 & $4,033.0$ & $4,437.0$ & $4,884.0$ & $5,437.0$ \\
\hline Myanmar & 46.7 & 49.4 & 54.8 & 62.4 & 69.5 & 77.8 & 88.6 & 100.6 & 117.4 \\
\hline Year & $\mathbf{2 0 0 6}$ & $\mathbf{2 0 0 7}$ & $\mathbf{2 0 0 8}$ & $\mathbf{2 0 0 9}$ & $\mathbf{2 0 1 0}$ & $\mathbf{2 0 1 1}$ & $\mathbf{2 0 1 2}$ & $\mathbf{2 0 1 3}$ & $\mathbf{2 0 1 4}$ \\
\hline China & 6,126 & 6,994 & 7,667 & 8,373 & 9,244 & 10,103 & 10,888 & 11,818 & 12,744 \\
\hline Myanmar & 119.9 & 126.5 & 132.5 & 138.2 & 144.4 & 151.3 & 158.9 & 167.5 & 177.6 \\
\hline
\end{tabular}

Empirical analysis is based on Myanmar bilateral trade data from 1997 to 2014 and establishes the gravity model using the least squares method to analyze the bilateral economic and trade. The economic distance between China and Myanmar can be considered unchanged, so is constant. The main analysis is about the bilateral trade and economic cooperation. Because of the establishment of a FTA between ASEAN and China promoting China and Myanmar trade development, so the model uses a dummy variable $W$ to reflect the effect of bilateral development. Before the establishment of the FTA, the dummy variable is 0 . And after the establishment of the FTA, the dummy variable is 1 . So the equation can be turned into the following form:

$$
L n T_{i j}=\beta_{0}+\beta_{1} \operatorname{Ln} Y_{i} Y_{j}+\beta_{2} W+\xi
$$

By using Eviews to analyze the data, the results are as follows:

$$
\begin{aligned}
& L n T_{i j}=-23.47+0.81 \operatorname{Ln} Y_{i} Y_{j}+0.68 \mathrm{~W} \\
& (-6.31) \quad(8.20) \quad(3.11) \\
& R^{2}=0.951 \quad \overline{R^{2}}=0.945 \quad F=147.64
\end{aligned}
$$

The result shows, in the formal, two variables pass through the $1 \%$ level of significance test, while the coefficient of determination is 0.95 . There is a positive correlation between the product of two countries' GDP and the total bilateral export-import volume. The results of model point out that when the product of two countries' GDP increased 1\%, the total export-import volume of China and Myanmar would grow $0.81 \%$ which means the development of the economies of both countries has positive effects on promoting bilateral trade and economic cooperation. And the China-Myanmar bilateral import and export volume and dummy variables are positively correlated which shows that the establishment of CAFTA has positive effects on China-Myanmar bilateral trade. Within the development of CAFTA, the economic transactions of both China and Myanmar will be promoted further.

\section{China- ASEAN Statistical Analysis}

To understand the distance effects, the study collects the total trade volume of ten ASEAN countries and China in 2014 while the distance is from the ten countries' capital to Beijing separately. The selected sample countries' data are drawn from the World Bank statistical database. Considering that the GDP of China is fixed in 2014, the paper analyzes the effect of distance directly. 
TABLE VII. ASEAN ECONOMIC AND TRADE DATA (2014)

\begin{tabular}{|l|c|c|c|}
\hline Country & Total Trade (million \$) & GDP (million \$) & Distance (km) \\
\hline Philippines & 44457.71 & 284777.09 & 2851 \\
\hline Indonesia & 63544.85 & 888538.20 & 5219 \\
\hline Brunei & 1936.53 & 17104.65 & 3899 \\
\hline Singapore & 79739.91 & 307859.75 & 4479 \\
\hline Thailand & 72621.16 & 404823.95 & 3297 \\
\hline Malaysia & 102005.63 & 338103.82 & 4346 \\
\hline Vietnam & 83636.41 & 186204.65 & 2326 \\
\hline Laos & 3617.36 & 11997.06 & 2778 \\
\hline Cambodia & 3757.65 & 16777.82 & 3351 \\
\hline Myanmar & 24968.93 & 64330.03 & 3227 \\
\hline
\end{tabular}

Using the gravity model, the panel data regression results are as follows:

TABLE VIII. Empirical Results of China AND Asean EConomic Trade

\begin{tabular}{lrlrr}
\hline \hline \multicolumn{1}{c}{ Variable } & Coefficient & Std. Error & t-Statistic & Prob. \\
\hline \hline C & 9.390290 & 5.751756 & 1.632595 & 0.1466 \\
LNY & 0.994296 & 0.120881 & 8.225388 & 0.0001 \\
LND & -1.328784 & 0.757740 & -1.753615 & 0.1229 \\
\hline \hline & & & & \\
R-squared & 0.908600 & Mean dependent var & 14.72791 \\
Adjusted R-squared & 0.882485 & S.D. dependent var & 1.527204 \\
S.E. of regression & 0.523532 & Akaike info criterion & 1.786889 \\
Sum squared resid & 1.918602 & Schwarz criterion & 1.877665 \\
Log likelihood & -5.934445 & Hannan-Quinn criter. & 1.687308 \\
F-statistic & 34.79301 & Durbin-Watson stat & 1.524296 \\
Prob(F-statistic) & 0.000231 & & & \\
\hline \hline
\end{tabular}

The trade gravity model empirical result of China and ASEAN economic trade is:

$$
\ln T_{i j}=9.29+\beta_{1} \ln Y_{i}+0.99 \ln Y_{j}-1.33 \ln D_{i j}
$$

The results show that there is a positive correlation between the trade volume and GDP of the ASEAN countries, but a negative correlation with the distance. When the Asean's member country' GDP grow 1\%, China and its trade volume may be increased by $0.99 \%$ relatively. AS China and Myanmar close to each other geographically, this advantage will develop the bilateral trade and economic growth.

\section{CONCLUSIONS}

Within the development of China-Asean FTA, the relationship of China and Myanmar economy has been deepened and the bilateral development prospect is considerable. In the future, the Asian Infrastructure Investment Bank (AIIB) financing support will strengthen the investment in China and Myanmar, and provide power to the national economy respectively. In order to push the China-Myanmar bilateral economic development forward, both sides could take positive actions and establish some experimental areas or zones At the same time, governments could establish assessment systems to promote the effective projects accessing resources preferentially and promoting industrial upgrading gradually.

In the future development process of "One Belt, One Road", both sides should strengthen the construction of the economic corridor and use the tariff concessions and other measures to enhance mutual investment. Myanmar is rich in natural resources which have the inherent advantages to attract industrial transfer and upgrade industrial structure. As for the existed industrial is omorphism, both China and Myanmar should optimize the product structure actively, improve the product quality and avoid vicious competition. Chinese investment to Myanmar should also comply with the principle of openness, fairness and maintain the benefits of Myanmar people. In order to expand the cooperation, China should develop science and technology, improve the export commodities quality and increase export of technology intensive products.

China and Myanmar should strengthen the cooperation on their own advantage industry such as the import and export processing industry, trade and logistics industry, tourism and cultural industry. In the future, the two countries should focus on the development of industries with forward-looking, emphasis on technology and knowledge which could bring the creative and upgrading power to the industry.

\section{ACKNOWLEDGMENT}

Thanks are due to Qin Yuhon for her invaluabl contributions during this collaboration and to Dr. Zhou Wei for valuable discussion. My paper is supported by the Key Scientific Research Foundation of Education Bureau of Yunnan Province, China (Grant No. 2015Z131).

\section{REFERENCES}

[1] C.L. Lu, "Analysis on the Difference of Regional Economic Integration between ASEAN and EU," Economic Vision, vol. 10, 2013, pp. 51-53.

[2] X.J. Zhang, "Study on the Effect of Regional Policy in EU Economic Integration: On the Enlightenment of China's Participation in Regional Economic Cooperation,” International Trade, vol. 7, 2007, pp. 35-40.

[3] Y. Zhou, and J.D. Tong, "European Sovereign Debt Crisis and EU Economic Integration," Nankai Journal, vol. 5, 2012, pp. 12-17.

[4] Y. Zhang, and Z.F. Tang, "Trade Gravity Model: Demonstration from China and Inspiration," Economic Survey, vol. 4, 2006, pp. 44-47. 